\title{
THE SMITHSONIAN INSTITUTION
}

\author{
REPORT FOR 1955-56
}

T HE report of the Secretary of the Smithsonian Institution* for the year ended June 30, 1956, which is accompanied by the financial report of the Executive Committee of the Board of Regents and the usual reports on the library and on publications and of the several branches of the Institution, refers to plans for the new building of the Museum of History and Technology. Construction of the foundations is to commence in the spring of 1957 and it is hoped that the building will be completed in 1960. Of other urgent building needs, the expansion of the Natural History Museum has the highest priority, but it is hoped that funds will also be provided to permit construction of a suitable building for the National Air Museum in close proximity to other units of the Institution. The new bird hall of the Natural History Museum was opened to the public in March 1956.

Special stress is laid by the Secretary on the expansion in the activities of the Smithsonian Astro. physical Observatory, the scientific headquarters of which have been moved to more adequate quarters in immediate association with the Harvard College Observatory in Cambridge, Massachusetts. As a consequence of this move, the Division of Astrophysical Research has re-appraised the basic scientific policies and objectives of the Observatory, and its broadened programme now includes research not only in solar activity and its effects upon the Earth but also meteoritic studies and studies of the upper atmosphere. In view of the deterioration in the atmospheric conditions caused by local smelting operations, the scientific equipment at Montezuma in Chile was moved to Table Mountain in Southern California, but there too the skies are showing progressive deterioration from smog from the urban area of Los Angeles. Records at Table Mountain also showed the increased atmospheric opacity arising from the Alaskan volcano in 1953 and from the explosions of nuclear or thermonuclear bombs. Another new programme of research is concerned with the nature and distribution of meteoritic debris and micro-meteorites; the nature of meteorite craters; exterior and terminal ballistics and the extraterrestrial life of meteorites, all from an astrophysical aspect. The Observatory has an important role in the artificial satellite tracking programme of the International Geophysical Year.

The Division of Radiation and Organisms continued its fundamental physiological and biochemical research on the role of light in regulating growth in higher plants. The action spectrum of the far-red reversal phenomenon observed last year in the excised stem hook or arch of seedlings of beans and other dicotyledonous plants that have been grown in complete darkness was completed and it has been found that the complete chlorophyll molecule is not formed immediately on irradiation of leaves of plants grown in the dark. Further studies on the effect of

* Smithsonian Institution. Report of the Secretary and Financial Report of the Executive Committee of the Board of Regents for the year ended June 30, 1956. Pp. ix $+211+8$ plates. (Smithsonian Offlce, 1956.) infra-red, far-red, and red radiant energy on the modification of chromosomal damage induced by X-rays using root tips of the horse bean, Vicia faba, indicate that infra-red irradiation, from 820 to 1,350 $\mathrm{m} \mu$, does not significantly increase $\mathrm{X}$-ray damage, but that far-red at 710-820 mu significantly increases the frequency of chromosomal aberrations induced by X-rays.

The Bureau of American Ethnology continued systematic studies in the archæological collections made in Panama, as well as archæological field-work in the Hudson Bay area. The La Venta excavations in Mexico were completed. Much assistance continued to be given to the programme for salvage archæology of the River Basins Surveys in areas to be flooded or otherwise destroyed by the construction of large dams. By the end of the period under review, survey parties had located and reported 4,365 archæological sites, of which 862 had been recommended for limited excavation, and 329 sites in 46 reservoir basins in seventeen States had been tested or partly dug.

Accessions to the United States National Museum totalled more than 900,000 specimens, including valuable collections of mammals from Siam and Africa, more than 230,000 termites and more than 10,000 invertebrates from the Antarctic, as well as the James Srnith Memorial Collection of fossil diatoms from the Philippines and important lots of plants from Brazil, New Guinea, Australia, Idaho and Alaska. Field work was conducted in Peru, Europe, Canada, Palau Archipelago, Libya, the West Indies, Panama and many parts of the United States. The galiery exhibit of the section of scientific instruments now consists of twelve units devoted to various fields beginning with weights and measures and ending with astrophysics.

Accessions to the National Air Museum numbered 118 specimens, and all the Museum's stored materials have now been moved to Suitland, Maryland. Reference is made to increasing demands on the Museum's information service. In all, 1,710 animals were added to the National Zoological Park during the year, and although the Park has no general research programme as such, a considerable amount of more or less specific research is carried out. Visitors reached a record total of $3,788,299$, while of the 440 visitors to the Canal Zone Biological Area, 51 were scientists using the station's facilities for special researches.

The International Exchange Service handled $1,161,855$ packages of government, scientific and literary publications, including 62 full and 42 partial sets of United States official publications, and con. signments were sent to all countries except China, North Korea, Outer Mongolia, Communist-controlled areas of Viet-Nam and Laos and the Haiphong Enclave. The Library received 78,715 publications during the year and arranged 237 new exchanges. A full list of the 74 new publications appearing under the Smithsonian imprint during the year is included in the report, and in all 424,389 copies of publications were distributed. 